\title{
POTENSI SENYAWA BIOAKTIF TANAMAN GENUS Phyllanthus SEBAGAI INHIBITOR REPLIKASI VIRUS HEPATITIS B
}

\section{Potency of Plant Bioactive Compounds from the Genus Phyllanthus as Hepatitis B Virus Replication Inhibitor}

\author{
Firdayani*, Susi Kusumaningrum, Yosephine Ria Miranti \\ Pusat Teknologi Farmasi dan Medika, Badan Pengkajian dan Penerapan Teknologi, Gedung 610-611 \\ Kawasan Puspiptek Tangerang Selatan 15314 \\ *Email: firdayani@bppt.go.id
}

\begin{abstract}
In this research, simulations of molecular docking of Phyllanthus bioactive compounds were performed into the core protein of HBV. This simulation aimed to predict the interaction between compounds with virus core protein causing disruption of capsid formation and inhibiting its replication. The docking simulation was completed by Molegro Virtual Docker 6.0. The 3D stable conformation of molecule structures were docked into HBV core protein downloaded from Protein Data Bank, then the results were analyzed to view the minimum energy and interactions that occurred. The coordinate docking was done at the same coordinate as the previously docked reference ligand position and was validated. From the results it was known that repandusinic acid formed the most stable affinity bond with amino acid residues of viral core proteins. Interaction of $B$ chain forming hydrogen bonds with the amino acid residues of Thr 33, Trp 102, Phe 23, Leu 140, Tyr 118 and Ser 141, and C chain with Thr 128, Val 124 and Glu 117. These compounds can be used as marker for anti HBV.
\end{abstract}

Keyword: Bioactive compounds, core protein, HBV , molecular docking, Phyllanthus

\section{ABSTRAK}

Pada penelitian ini dilakukan simulasi penambatan molekul senyawa-senyawa bioaktif Phyllanthus ke dalam protein inti virus hepatitis B. Simulasi ini bertujuan untuk memprediksi interaksi terbentuk antara senyawa dengan protein yang menyebabkan terganggunya pembentukan kapsid virus dan menghambat replikasinya. Simulasi penambatan molekul dilakukan menggunakan program Molegro Virtual Docker 6.0. Sebagai reseptor target digunakan struktur 3D protein inti yang diunduh dari Protein Data Bank. Posisi penambatan dilakukan pada koordinat yang sama dengan posisi ligan referensi yang sudah tertambat sebelumnya dan tervalidasi. Dari hasil simulasi diketahui bahwa asam repandusinat membentuk komplek dengan energi afinitas ikatan yang paling kecil dengan residu asam amino protein inti virus. Interaksi terjadi dengan rantai B yang membentuk ikatan hidrogen dengan asam amino Thr 33, Trp 102, Phe 23, Leu 140, Tyr 118 dan Ser 141, dan rantai C dengan asam amino Thr 128, Val 124 dan Glu 117. Senyawa ini dapat dijadikan sebagai marka untuk anti VHB.

Kata kunci: Penambatan molekul, Phyllanthus, protein inti, senyawa bioaktif, VHB 


\section{PENDAHULUAN}

Hepatitis B adalah penyakit infeksi hati yang berpotensi mengancam jiwa yang disebabkan oleh virus hepatitis B (VHB). Penyakit ini merupakan masalah kesehatan global karena dapat menyebabkan penyakit hati kronis dan menempatkan pasien pada risiko tinggi kematian. Diperkirakan sekitar 240 juta orang di dunia terinfeksi secara kronis oleh hepatitis B yang didefinisikan dengan mempunyai HBsAg positif setidaknya selama 6 bulan. Lebih dari 686 ribu orang meninggal tiap tahun akibat komplikasi hepatitis B termasuk sirosis dan kanker hati (Naghavi et al. 2015). Sekitar $75 \%$ penderita hepatitis B kronis berada di Asia. Endemis di Indonesia termasuk dalam level sedang hingga tinggi di beberapa wilayahnya (Kemenkes 2014; Yano et al. 2015).

Obat untuk hepatitis B yang telah disetujui FDA saat ini ada 2 jenis, yaitu immunomodulator (IFN- $\alpha$ dan peg-IFN- $\alpha$ ) dan analog nukleosida (lamivudin, adefovir dipivoksil, entecavir, telbivudin, tenofovir disoproksil fumarat). Interferon tidak aktif jika diberikan secara oral melainkan harus diberikan secara intravena atau subkutan dan dimetabolisme di dalam hati. Analog nukleosida bekerja dengan menghambat fungsi DNA polimerase virus dengan target reverse transcriptase (RT) VHB. Namun setelah penggunaan obat cukup lama, dapat terjadi efek samping akibat resistensi dan mutasi spesifik pada virus. Dengan demikian, masih diperlukan usaha dan penelitian untuk mencari dan menemukan obat baru untuk mengatasi penyakit akibat VHB.

Protein inti VHB merupakan target obat yang sedang diteliti akhir-akhir ini. Protein inti ini memegang peranan penting pada berbagai tahap siklus hidup virus, yaitu berinteraksi dengan protein inang dan membentuk kapsid yang cukup stabil untuk melindungi RNA dan DNA virus serta dapat melepaskan DNA virus pada saat yang tepat dalam siklus kehidupan virus. Dengan mengganggu peran protein inti ini maka replikasi virus akan terhambat. Oleh karena itu protein inti VHB ini merupakan target yang sangat baik untuk pengembangan antivirus baru yang selektif, aman dan efektif (Bourne et al. 2008; Campagna et al. 2013; Klumpp et al. 2015; Zlotnick et al. 2015; Venkatakrishnan et al. 2016).
Genus Phyllanthus merupakan kelompok tumbuhan famili Euphorbiaceae yang terdiri dari 1000 spesies dan terdapat di daerah tropis maupun subtropis. Phyllanthus merupakan genus tanaman yang sebagian besar anggotanya telah digunakan sebagai obat herbal. Salah satu khasiat yang dimiliki dan banyak diteliti adalah sebagai anti hepatitis $\mathrm{B}$, baik secara in vitro, in vivo maupun uji klinis (Mao et al. 2016). Ekstrak air dari tanaman meniran hijau (Phyllanthus niruri) menghambat endogenous DNA polimerase dari VHB dan berikatan dengan antigen permukaan (HBsAg) virus secara in vitro (Venkateswaran et al. 1987). Senyawa aktif yang dikandungnya antara lain nirtetralin. Nirtetralin A dan nirtetralin B mampu menekan sekresi $\mathrm{HBsAg}$ dan $\mathrm{HBeAg}$ secara in vitro dengan nilai $I C_{50}$ pada satuan mikromolar (Wei et al. 2012). Pasien yang menerima perlakuan ekstrak Phyllanthus urinaria (L), kadar HBsAg yang terdeteksi dari serumnya menurun (Wang et al. 1995; Xia et al. 2013). Sekresi HBsAg dan HBeAg juga menunjukkan penurunan secara signifikan setelah pemberian nirtetralin pada cell line HepG2.2.15 (Liu et al. 2014). Sedangkan asam elagat tidak menunjukkan efek pada replikasi VHB.

Tanaman Phyllanthus telah dilaporkan mengandung senyawa seperti flavonoid, alkaloid, terpenoid, lignan, polifenol, tannin, coumarin, dan saponin. Beberapa senyawa yang telah dilaporkan terkandung dalam Phyllanthus (Gambar 1-7)

Penambatan molekular (molecular docking) adalah prosedur komputasional yang bekerja untuk memprediksi ikatan nonkovalen antar makromolekul atau lebih seringnya pada makromolekul (reseptor) dan molekul kecil (ligan) secara efisien. Simulasi penambatan molekul bertujuan untuk memprediksi konformasi ikatan dan afinitas ikatan sehingga dapat digunakan untuk memilah senyawa-senyawa mirip obat sebagai senyawa penuntun untuk dikembangkan menjadi kandidat obat selanjutnya. Tujuan dari penelitian ini adalah untuk mengetahui interaksi yang terjadi antara senyawa bioaktif yang dikandung oleh tanaman dalam genus Phyllanthus dengan protein inti VHB menggunakan teknik simulasi penambatan molekul. Dengan melihat hasil simulasi ini dapat diprediksi senyawa yang berperan dalam replikasi VHB sehingga 
<smiles>C[C@@H]1[C@@H](O)CO[C@H](CO[C@H]2O[C@H](Oc3c(-c4ccc(O)c(O)c4)oc4cc(O)cc(O)c4c3=O)C(=O)[C@H](O)[C@@H]2O)[C@@H]1O</smiles>

Rutin<smiles>CC(C)=CCc1c(O)c(O)c(O[C@@H]2O[C@H](C)[C@@H](O)[C@H](O)[C@H]2O)c2c1O[C@H](c1ccc(O)cc1)CC2=O</smiles>

Nirutin<smiles>O=C1c2c(O)cc(O)cc2O[C@H](c2ccc(O)cc2)[C@@H]1O[C@H]1C[C@H](O)[C@@H](O)[C@H](O)[C@H]1O</smiles>

Astragalin

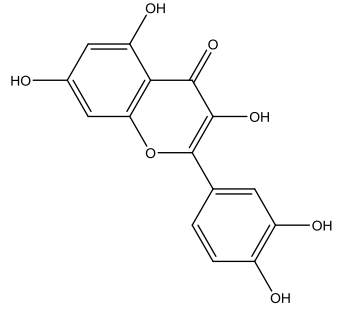

Quercetin

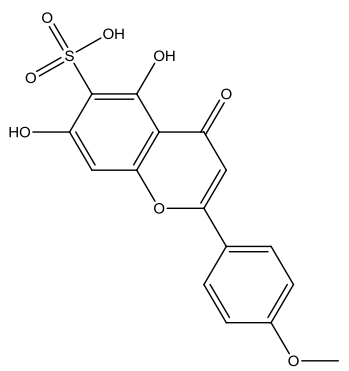

Niruriflavone

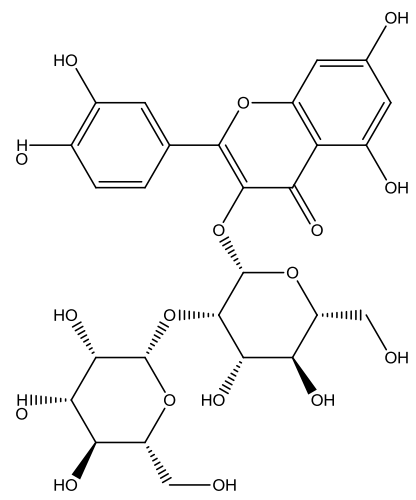

Quercetine 3-o- $\beta-D$ glucopyranoyl-(2-1)-o- $\beta-D$ xylapyranoside<smiles>Oc1cc(O)c2c(c1)O[C@H](c1cc(O)c(O)c(O)c1)[C@H](O)C2</smiles>

Gallocatechin<smiles>COc1cc2c(c3c1[C@H](O)[C@H](O)[C@H](c1ccccc1)O3)C=CC(C)(C)O2</smiles>

Quercetol<smiles>C[C@H]1O[C@@H](Oc2c(-c3ccc(O)c(O)c3)oc3cc(O)cc(O)c3c2=O)[C@H](O)[C@H](O)[C@@H]1O</smiles>

Quercitrin

Gambar 1. Struktur senyawa golongan flavonoid dalam Phyllanthus<smiles>C=C(C)[C@H]1CC=C(C)CC1</smiles>

Limonene

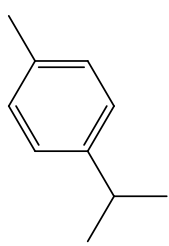

Cymene

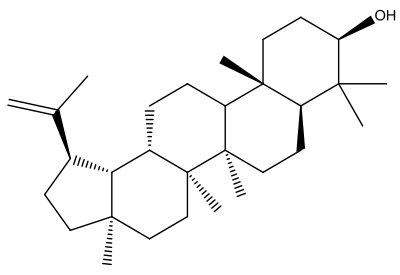

Lupeol

Gambar 2. Struktur senyawa golongan terpenoid dalam Phyllanthus 


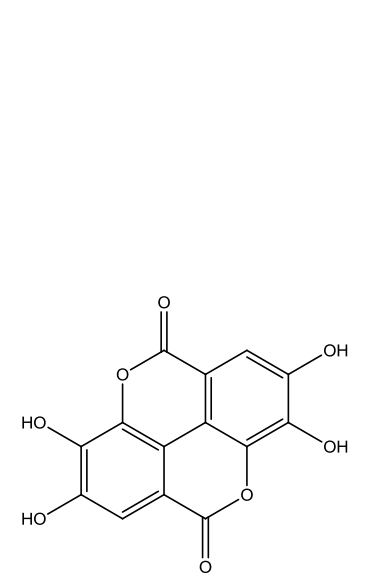

Elagic acid

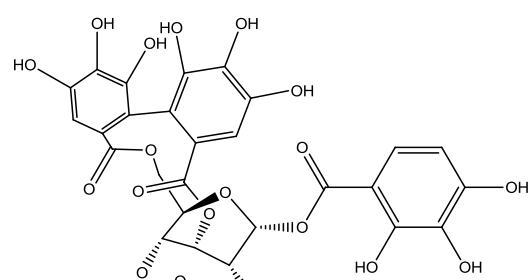

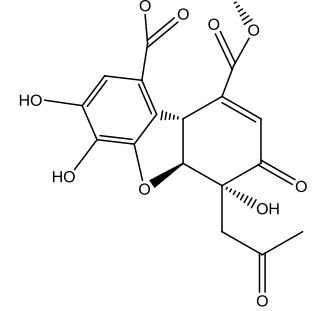

Ellagitannin

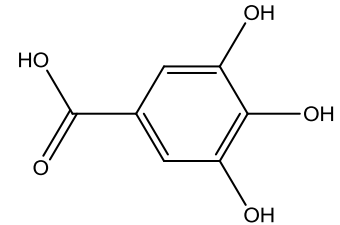

Gallic acid

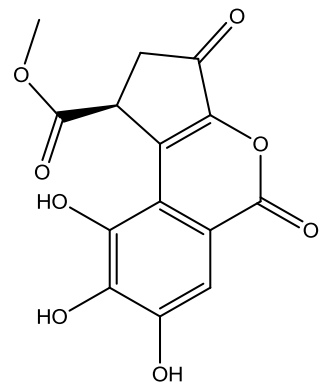

Metil brevifolinkarboksilat

Gambar 3. Struktur senyawa golongan coumarin dalam Phyllanthus

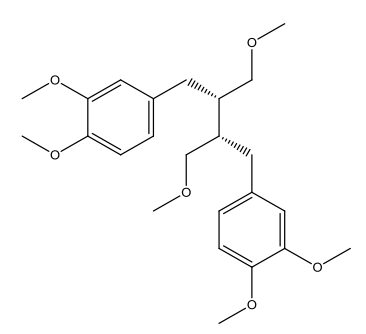

Phyllantin

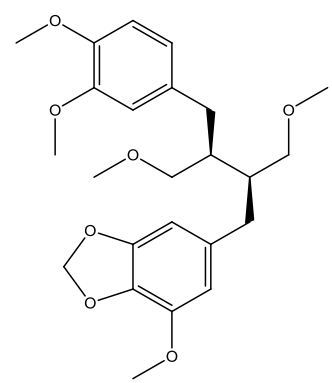

Lintetralin

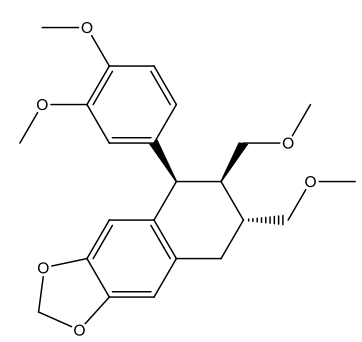

Isolintetralin

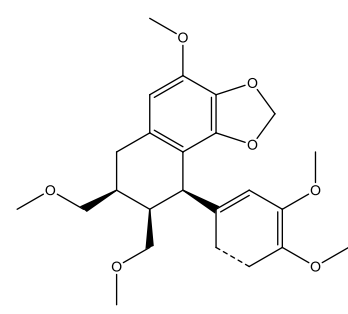

Hipophyllantin

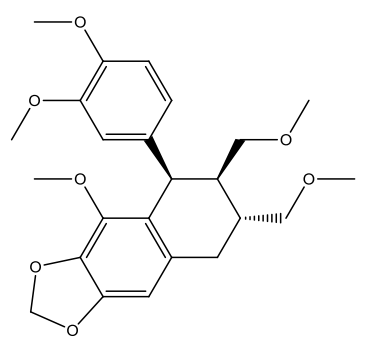

Phyltetralin<smiles>COc1ccc(C[C@@H](CO)[C@H](CO)Cc2ccc3c(c2)OCO3)cc1OC</smiles>

2,3-Desmethoxy seco-isolintetralin

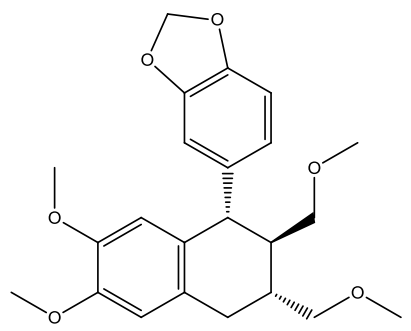

Niranthin<smiles>COC[C@H]1Cc2cc(OC)c(OC)cc2[C@@H](c2ccc(OC)c(OC)c2)[C@@H]1COC</smiles>

Nirtetralin

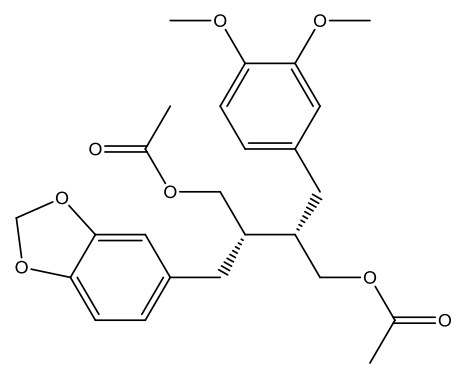

2,3-Desmethoxy secoisolintetralindiacetate

Gambar 4. Struktur senyawa golongan lignan dalam Phyllanthus 


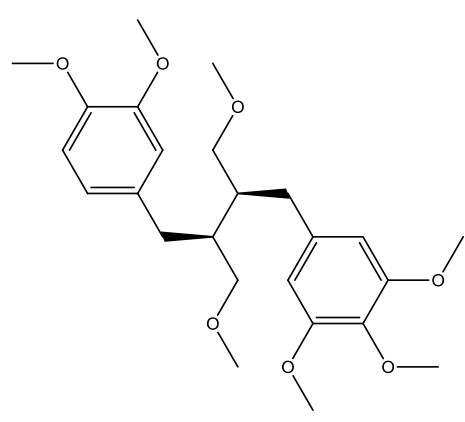

Linnanthin

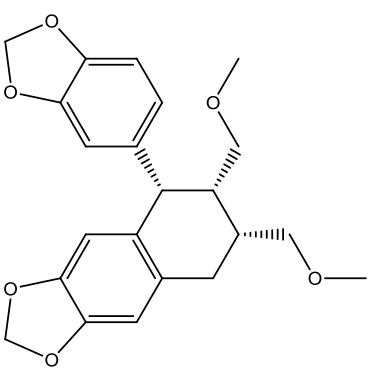

Urinatetralin

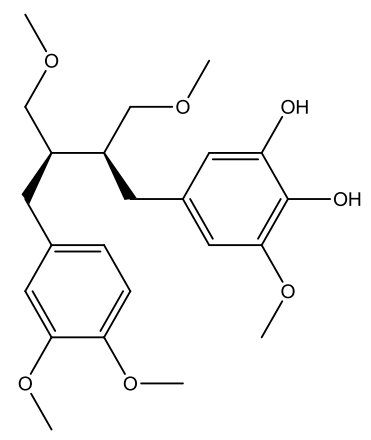

Demethylenedioxyniranthin

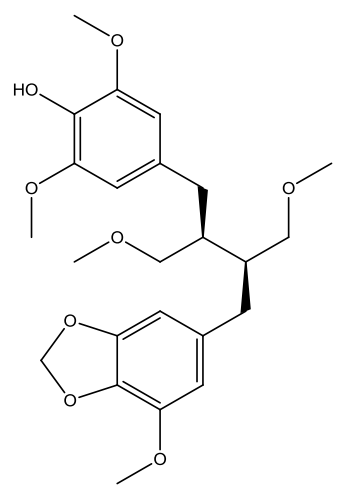

Nirphyllin

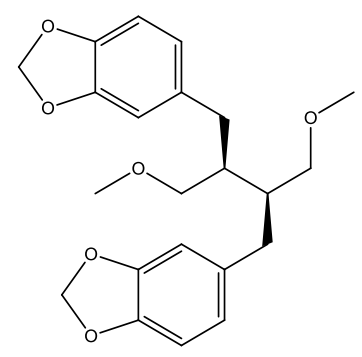

Cubebin dimethyl ether

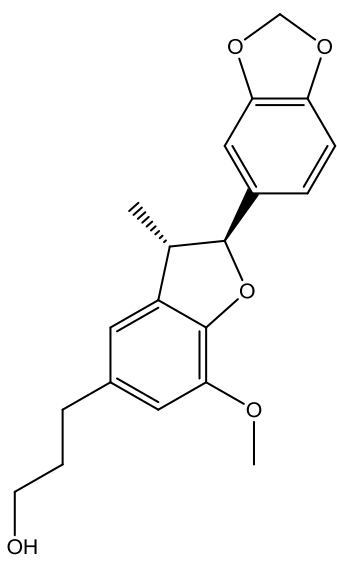

Phylinirurin<smiles>COC[C@H](CO)[C@@H](COC)[C@H](c1ccc(OC)c(OC)c1)c1ccc2c(c1)OCO2</smiles>

Seco-4-hydroxylintetralin<smiles>COC[C@@H]([C@H](O)c1ccc(OC)c(OC)c1)[C@H](COC)Cc1cc(OC)c2c(c1)OCO2</smiles>

Hydroxyniranthin

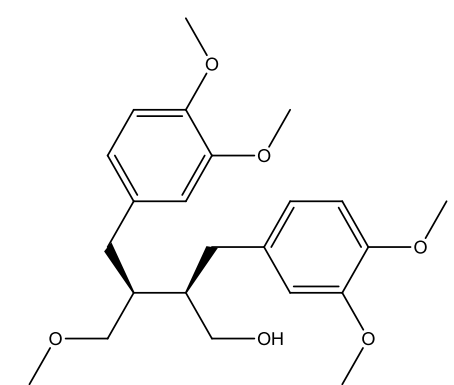

Seco-Isolarisiresinoltrimethyl ether

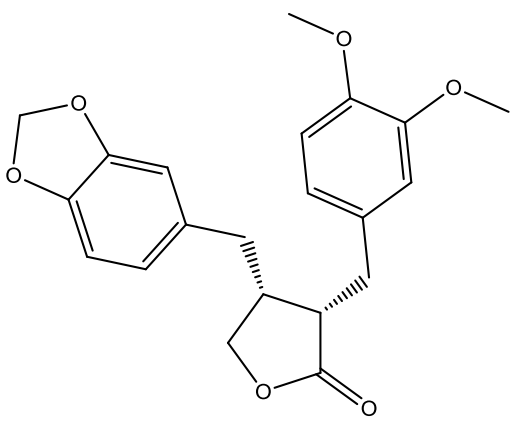

3,4-Methylenedioxybenzyl-3',4'dimethoxybenzylbutyrolactone

Gambar 5. Struktur senyawa golongan tannin dalam Phyllanthus (bersambung ke halaman berikutnya) 


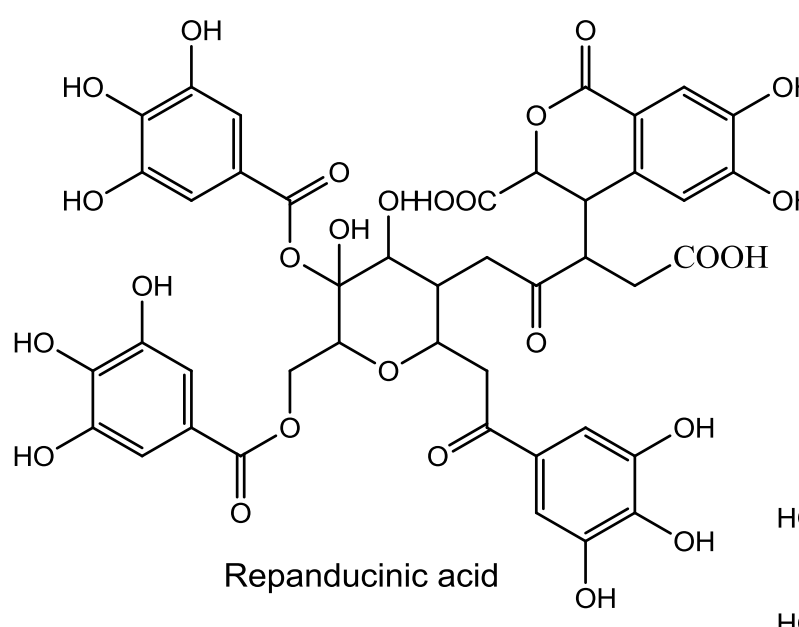<smiles>O=C(OCC1OC(OC(=O)c2cc(O)c(O)c(O)c2)C(O)C(O)C1(O)OC(=O)c1cc(O)c(O)c(O)c1)c1cc(O)c(O)c(O)c1</smiles>

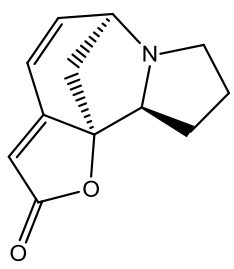

Norsecurinine

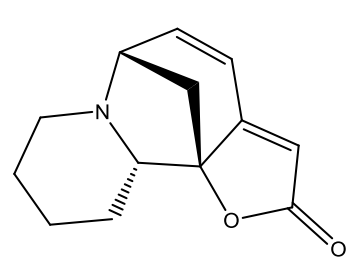

Securinine

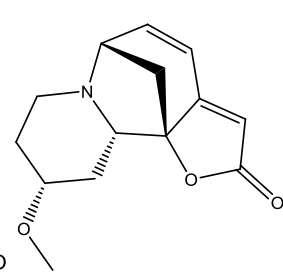

Phylanthine

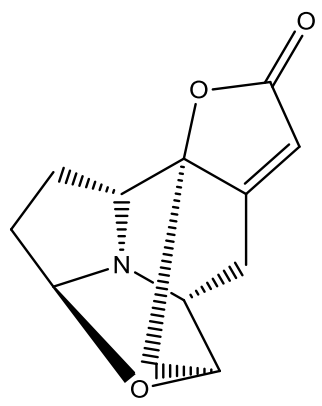

Nirunine

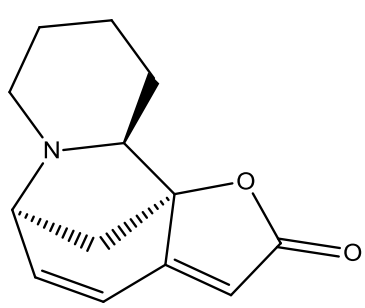

Phyllochrysine

Gambar 7. Struktur senyawa golongan alkaloid dalam Phyllanthus 
dapat dijadikan sebagai marka atau sebagai senyawa penuntun untuk dikembangkan lebih lanjut.

\section{BAHAN DAN METODE}

Prosesor AMD Athlon ${ }^{\mathrm{TM}}{ }_{\mathrm{II}} \mathrm{X} 3 \quad 445$ dengan RAM 4 GB dan windows 32-bit sebagai sistem operasi. Struktur senyawa aktif diperoleh dari beberapa publikasi baik nasional maupun internasional. Struktur kristal protein inti VHB yang digunakan sebagai reseptor diperoleh dari Protein Data Bank (PDB) yang diakses melalui URL http://www.rscb.org/pdb dengan kode: 5GMZ. Protein ini dengan resolusi $1,7 \AA$, yang membentuk komplek dengan senyawa 4-metil heteroarildihidropirimidin. Metode penambatan molekul dilakukan menggunakan software Molegro Virtual Docker (MVD) 6.0.

Senyawa aktif atau ligan yang telah digambar struktur 2D kemudian dikonversi menjadi 3D dan ditentukan konformasi yang paling stabil. Struktur disimpan dalam format .mol2. Struktur reseptor dimasukkan ke dalam program MVD 6.0 dengan tidak menyertakan molekul air. Selanjutnya dilakukan analisis penambatan untuk melihat energi minimum dan interaksi yang terjadi seperti adanya ikatan hidrogen yang dihasilkan dari kompleks tersebut. Validasi metode dilakukan dengan mengekstrak ligan yang sudah terdapat dalam protein dan dilakukan proses penambatan. Metode penambatan dinyatakan valid apabila diperoleh nilai Root Mean Square Deviation (RMSD) kurang dari 2,0 $\AA$ (Hevener et al. 2009) Selanjutnya ligan emodin dan turunannya diimpor ke dalam program dan dilakukan pensejajaran (alignment) dengan ligan referensi. Simulasi penambatan dilakukan untuk masing-masing senyawa tersebut dengan mengubah menjadi ligan aktif (set as active ligand) dan dianalisis hasilnya.

\section{HASIL DAN PEMBAHASAN}

Tujuan utama simulasi penambatan molekul adalah untuk memahami dan memprediksi cara kerja obat pada tingkat molekul dengan melihat interaksi obat dengan reseptor. Protein inti merupakan target obat yang diteliti dan dikembangkan akhir-akhir ini untuk mencari antivirus hepatitis B baru. Protein inti ini memegang peranan penting pada berbagai tahap siklus hidup virus, yaitu berinteraksi dengan protein inang dan membentuk kapsid yang cukup stabil untuk melindungi RNA dan DNA virus serta dapat melepaskan DNA virus pada saat yang tepat dalam siklus kehidupan virus. Protein inti VHB terdiri dari 183-185 asam amino yang membentuk domain $\mathrm{N}$-terminal (asam amino 1-149) untuk perakitan kapsid dan domain Cterminal (asam amino 150-185) untuk mengikat asam nukleat.

Sebagai model reseptor dalam pemodelan molekul ini dipilih protein inti VHB dengan PDB ID: 5GMZ. Struktur tiga dimensi protein ini dipilih karena memiliki resolusi tinggi yaitu 1,7 $\AA$ dan telah tertambat oleh ligan kokristal senyawa dari 4-metil heteroarildihidropirimidin di dalamnya. Protein $5 \mathrm{GMZ}$ ini terdapat 6 monomer protein dan masing-masing telah tertambat oleh ligan-ligan berikatan pada antarmuka dimer-dimer dari protein inti, membentuk suatu interaksi permukaan protein-protein baru, menginduksi perakitan protein dan meningkatkan stabilitas (Qiu et al. 2016). Dengan demikian posisi dan koordinat ligan ini dapat dijadikan referensi untuk penambatan senyawa lain yang dirancang sebagai kandidat inhibitor baru.

Sebelum simulasi penambatan dilakukan terhadap ligan emodin dan turunannya, dilakukan re-docking ligan referensi ke dalam protein inti VHB. Validasi metode dilakukan dengan mengekstraksi ligan yang ada dalam protein dan dilakukan proses penambatan kembali (re-docking). RMSD adalah patokan untuk akurasi dari posisi tambatan (docking pose). RSMD antara posisi tambatan yang dihasilkan dan konformasi ligan eksperimental menunjukkan patokan untuk kemampuan algoritma docking untuk memprediksi konformasi protein yang terikat ligan. RMSD relatif mengacu pada langkah penjajaran tambahan molekul-molekul sebelum perhitungan RMSD yang sebenarnya. Mode ini berguna untuk investigasi keakuratan model generator konformasi. Nilai RMSD yang baik jika bernilai kurang dari 2,0 $\AA$ (Vyas et al. 2008).

Penambatan molekul kembali ligan referensi pada daerah antarmuka rantai $B$ dan C sebagai tempat penambatan untuk skrining selanjutnya terhadap senyawa aktif dalam Phyllanthus. Daerah penambatan dilakukan pada koordinat $x=-25,15 ; y=-8,83$; dan $z=-6,76$ dalam radius/dimensi: $15 \AA$ yang memberikan nilai RMSD rata-rata dari 3 kali pengulangan sebesar 0,7 Á dengan rerank skor -140,87. 
Tabel 1. Hasil simulasi penambatan senyawa aktif Phyllanthus ke dalam reseptor protein inti VHB (PDB ID: 5GMZ)

\begin{tabular}{|c|c|c|c|}
\hline No & Senyawa & $\begin{array}{c}\text { Skor } \\
\text { reranking }\end{array}$ & $\begin{array}{c}\text { Energi ikatan } \\
\text { Hidrogen }\end{array}$ \\
\hline 1 & Repandusinic acid & -156 & $-19,7$ \\
\hline 2 & Corilagin & -138 & $-15,0$ \\
\hline 3 & Rutin & -133 & $-14,3$ \\
\hline 4 & 1-O-galloyl-6-O-luteolyl-alpha-D-glucoside & -124 & $-16,9$ \\
\hline 5 & Nirurin & -124 & $-7,3$ \\
\hline 6 & Phyltetralin & -116 & 0 \\
\hline 7 & Nirphyllin & -115 & $-2,3$ \\
\hline 8 & Cubebin dimethyl ether & -115 & $-0,03$ \\
\hline 9 & 2,3-Desmethoxy seco-isolintetralin & -114 & $-6,5$ \\
\hline 10 & Astragalin & -113 & $-12,6$ \\
\hline 11 & Quercitrin & -112 & $-10,8$ \\
\hline 12 & Beta-Glucogallin & $-111,5$ & $-13,6$ \\
\hline 13 & Demethylenedioxynirantin & $-108,5$ & $-5,7$ \\
\hline 14 & Urinatetralin & -107 & 0 \\
\hline 15 & Isolintetralin & -106 & 0 \\
\hline 16 & Quersetin 3-O-Beta-D-glucopyranosil-(2-1)-O-Beta-D-xylopyranocide & -105 & $-11,7$ \\
\hline 17 & Seco-isolariciresinol trimethyl ether & -104 & -2.5 \\
\hline 18 & Gallocatekin & -102 & $-10,4$ \\
\hline 19 & 2,3-Desmetoxy seco-isolintetralin diacetate & -102 & $-3,5$ \\
\hline 20 & Linnantiin & -102 & $-2,0$ \\
\hline 21 & Seco-4-hydroxylintetralin & -100 & $-3,3$ \\
\hline 22 & Lintetralin & -100 & -0.15 \\
\hline 23 & Hidroxyiniranthin & -98 & $-2,4$ \\
\hline 24 & Methyl brevifolincarboxylate & -97 & $-8,7$ \\
\hline 25 & Quersetol & -96 & $-0,9$ \\
\hline 26 & 3,4-Methylenedioxybenzil-3'-4'-dimetoxyibenzilbutirolacton & -94 & $-3,9$ \\
\hline 27 & Hipophylantine & -94 & $-1,4$ \\
\hline 28 & Phylantin & -94 & 0 \\
\hline 29 & Hexahydroxyldiphenoyl & -92 & $-13,4$ \\
\hline 30 & Quersetin & -92 & $-4,2$ \\
\hline 31 & Phylnirurin & -89 & $-4,96$ \\
\hline 32 & Niruriflavone & -87 & $-4,7$ \\
\hline 33 & Elagic acid & -87 & $-2,6$ \\
\hline 34 & Niranthin & -87 & $-1,5$ \\
\hline 35 & Ellagitannin & -85 & $-14,7$ \\
\hline 36 & Diosgenin & -83 & $-2,6$ \\
\hline 37 & Lupeol & -78 & -2.5 \\
\hline 38 & Nirtetralin & -75 & $-1,8$ \\
\hline 39 & Gallic acid & -73 & $-11,6$ \\
\hline 40 & Sekurinin & -72 & -2.5 \\
\hline 41 & Phylocricin & -70 & $-21,2$ \\
\hline 42 & Norsekurinin & -68 & -2.5 \\
\hline 43 & Nirunine & -61 & 0 \\
\hline 44 & Geraniin & -60 & $-13,7$ \\
\hline 45 & Limonen & -51 & 0 \\
\hline 46 & p-cymen & -49 & 0 \\
\hline 47 & Niruricide & -27 & $-9,0$ \\
\hline
\end{tabular}




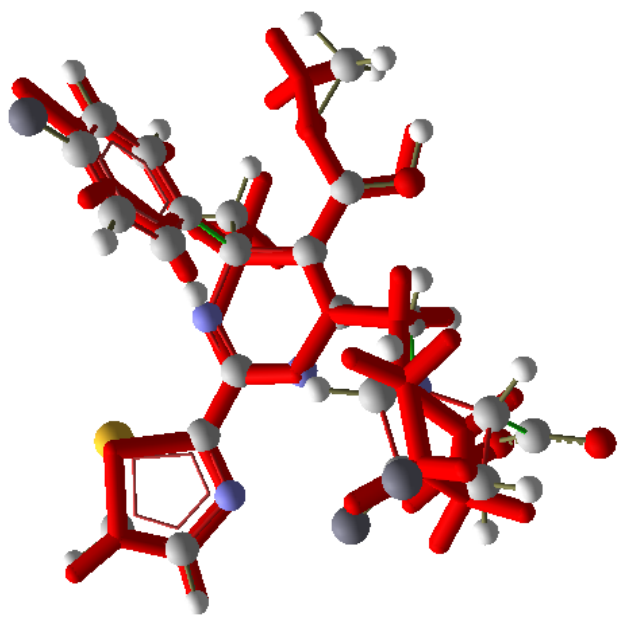

Gambar 8. Posisi ligan referensi sebelum dan setelah ditambatkan kembali (re-docking). Molekul dalam model ball and stick merupakan posisi awal sedangkan bentuk stick setelah dilakukan re-docking dengan RMSD 0,7 ̊́

Berdasarkan hasil simulasi penambatan molekul, dapat diprediksi bahwa beberapa senyawa aktif dari tanaman Phyllanthus memiliki ikatan yang stabil (energi afinitas ikatan atau skor reranking benilai negatif) dengan protein inti VHB. Hal ini merupakan indikasi bahwa senyawa tersebut memiliki aktivitas dalam mengintervensi struktur protein inti VHB. Semakin negatif nilai skor reranking identik dengan energi ikatan yang semakin stabil. Oleh karenanya, senyawa ini akan mengganggu atau menghambat replikasi VHB dan berakibat terganggunya pembentukan kapsid yang dirakit oleh protein inti $(\mathrm{HBc})$ yang berikatan pada daerah antarmuka dimer-dimer protein, sehingga kapsid berbentuk tidak seragam lagi. Senyawa asam repandusinat dari golongan tannin mempunyai nilai atau skor yang tertinggi dibandingkan dengan senyawa lain dalam Phyllanthus, bahkan melebihi nilai atau skor dari senyawa 4-metil heteroarildihidropirimidin yang merupakan inhibitor protein inti telah teruji memiliki aktivitas penghambat pembentukan kapsid VHB. Interaksi senyawa ini dengan protein inti VHB dimungkinkan dengan banyaknya gugus fenol yang membentuk ikatan hidrogen dengan residu asam amino pada protein inti baik dengan rantai B maupun rantai C. Adanya ikatan dan interaksi ini akan membuat terganggunya pembentukan dimer protein inti yang akan berakibat

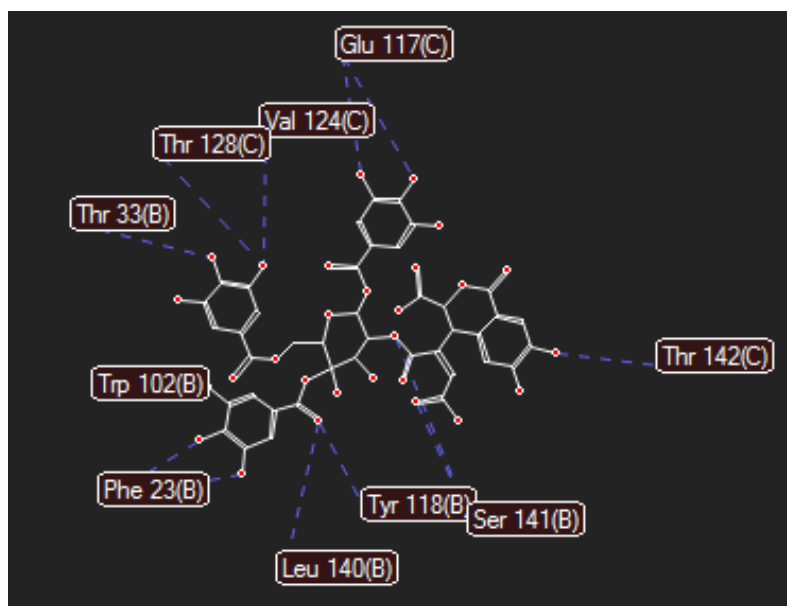

Gambar 9. Interaksi asam repandusinat dengan residu asam amino dari protein inti VHB. Garis biru putus-putus menunjukkan ikatan hidrogen.

terhambatnya pembentukan kapsid virus yang seragam sehingga akan menghambat replikasi virus.

Gambar 9 menunjukkan interaksi yang berupa ikatan hidrogen yang terjadi antara senyawa asam repandusinat dengan residu asam amino dari reseptor. Gugus fenol dari asam repandusinat berinteraksi dengan rantai $B$ residu asam amino Thr 33, Trp 102 dan Phe 23. Sedangkan dengan rantai $C$ membentuk ikatan hidrogen dengan asam amino Thr 128, Val 124 dan Glu 117. Selain itu atom oksigen dari gugus karbonil pada senyawa ini berinteraksi membentuk ikatan hidrogen dengan Leu 140 Tyr 118 dan Ser 141 dari rantai B protein inti VHB.

Senyawa asam repandusinat ini diketahui merupakan senyawa yang berpotensi menghambat enzim reverse transcriptase HIV-1 dan juga replikasi VHB (Lewis dan Elvin-Lewis 2003; Sarin et al. 2014). Namun belum ada penjelasan lebih lanjut mengenai mekanisme penghambatan senyawa ini terhadap VHB. Dengan demikian penelitian ini dapat memprediksi mekanisme penghambatannya secara in silico melalui interaksinya dengan protein inti virus.

Namun sayangnya, senyawa ini memiliki berat molekul yang besar yaitu 972 Dalton sehingga tidak memungkinkan untuk dijadikan kandidat obat oral, yang biasanya di bawah 500 Dalton sesuai dengan aturan Lipinski (Lipinski 2004). Akan tetapi tidak menutup kemungkinan senyawa ini dikembangkan menjadi marka bagi ekstrak tanaman dalam genus Phyllanthus untuk 
aktivitas anti VHB. Untuk senyawa lain dalam Phyllanthus berpotensi pula untuk dikembangkan sebagai kandidat obat hepatitis B dengan melakukan modifikasi struktur.

\section{KESIMPULAN}

Tanaman dalam genus Phyllanthus mempunyai aktivitas sebagai anti VHB. Berdasarkan hasil simulasi penambatan molekul, diprediksi senyawa asam repandusinat mempunyai aktivitas menghambat replikasi virus melalui penghambatan pembentukan kapsid yang dibentuk dimer-dimer protein inti VHB. Walaupun tidak memungkinkan untuk dijadikan kandidat obat oral, senyawa asam repandusinat bisa dikembangkan menjadi marka bagi ekstrak tanaman dalam genus Phyllanthus untuk aktivitas anti VHB.

\section{UCAPAN TERIMA KASIH}

Tulisan ini merupakan hasil kegiatan yang didanai oleh Kementerian Riset, Teknologi dan Pendidikan Tinggi melalui Program Insentif Sistem Inovasi Nasional (Insinas) tahun 2017.

\section{DAFTAR PUSTAKA}

Bourne C, Lee S, Venkataiah B, Lee A, Korba B, Finn MG, Zlotnick A (2008) Small-molecule effectors of hepatitis B virus capsid assembly give insight into virus life cycle. J Virol 82:1026210270. doi: 10.1128/JVI.01360-08

Campagna MR, Liu F, Mao R, Mills C, Cai D, Guo F, Zhao X, Ye H, Cuconati A, Guo H, Chang J, Xu X, Block TM, Guo JT (2013) Sulfamoylbenzamide derivatives inhibit the assembly of hepatitis B virus nucleocapsids. J Virol 87:6931-6942. doi: 10.1128/JVI.0058213

Hevener KE, Zhao W, Ball DM, Babaoglu K, Qi J, White SW, Lee RE (2009) Validation of molecular docking programs for virtual screening against dihydropteroate synthase. J Chem Inf Model 49:444-460. doi: $10.1021 / \mathrm{ci} 800293 \mathrm{n}$

Kemenkes (2014) InfoDATIN: Situasi dan analisis hepatitis. Pekan peduli hepatitis B, 4-12 September. Pusat
Data dan Informasi Kementerian Kesehatan RI, Jakarta

Klumpp K, Lam AM, Lukacs C, Vogel R, Ren $\mathrm{S}$, Espiritu C, Baydo R, Atkins $\mathrm{K}$, Abendroth J, Liao G, Efimov A, Hartman G, Flores OA (2015) Highresolution crystal structure of a hepatitis B virus replication inhibitor bound to the viral core protein. Proc Natl Acad Sci USA 112:15196-15201. doi: 10.1073/pnas. 1513803112

Lewis WH, Elvin-Lewis MPF (2003) Medical Botany: Plants Affecting Human Health. Second Edition. John Wiley \& Sons Inc, New Jersey

Lipinski CA (2004) Lead- and drug-like compounds: the rule-of-five revolution. Drug Discov Today Technol 1:337341. doi: 10.1016/j.ddtec.2004.11.007

Liu S, Wei W, Li Y, Lin X, Shi K, Cao X, Zhou M (2014) In vitro and in vivo antihepatitis $B$ virus activities of the lignan nirtetralin $B$ isolated from Phyllanthus niruri L. J Ethnopharmacol 157:62-68. doi: 10.1016/j.jep.2014.09.019

Mao X, Wu LF, Guo HL, Chen WJ, Cui YP, Qi Q, Liang WY, Yang GH, Shao YY, Zhu D, She GM, You Y, Zhang LZ (2016) The genus Phyllanthus: An Ethnopharmacological, phytochemical, and pharmacological review. Evidence-Based Complementary and Alternative Medicine 2016:7584952. doi: $10.1155 / 2016 / 7584952$

Naghavi M, Wang H, Lozano R \& 700 others (2015) Global, regional, and national age-sex specific all-cause and causespecific mortality for 240 causes of death, 1990-2013: a systematic analysis for the global burden of disease study 2013. Lancet, 385:117171. doi: 10.1016/S01406736(14)61682-2

Qiu Z, Lin X, Zhou M, Liu Y, Zhu W, Chen W, Zhang W, Guo L, Liu H, Wu G, Huang M, Jiang M, Xu Z, Zhou Z, Qin N, Ren S, Qiu H, Zhong S, Zhang $Y$, Zhang $Y$, Wu X, Shi L, Shen F, Mao $Y$, Zhou $X$, Yang W, Wu JZ, Yang G, Mayweg AV, Shen HC, Tang G (2016) Design and synthesis of orally bioavailable 4-methyl heteroaryldihydropyrimidine based hepatitis B virus (HBV) capsid inhibitors. J Med Chem 59:7651-7666. 
doi: 10.1021/acs.jmedchem.6b00879

Sarin B, Verma N, Martin JP, Mohanty A (2014) An overview of important ethnomedicinal herbs of Phyllanthus spesies: Present status and future prospects. Sci World J 2014:839172. doi: 10.1155/2014/839172

Venkatakrishnan B, Katen SP, Francis S, Chirapu S, Finn MG, Zlotnick A (2016) Hepatitis B virus capsids have diverse structural responses to small-molecule ligands bound to the heteroaryldihydropyrimidine pocket. J Virol 90:3994-4004. doi: 10.1128/JVI.03058-15

Venkateswaran PS, Millman I, Blumberg BS (1987) Effects of an extract from Phyllanthus niruri on hepatitis B and woodchuck hepatitis viruses: In vitro and in vivo studies. Proc Natl Acad Sci USA 84:274-278. doi: 10.1073/pnas.84.1.274

Vyas V, Jain A, Jain A, Gupta A (2008) Virtual screening: A fast tools for drug design. Sci Pharm 76:333-360. doi: 10.3797/scipharm.0803-03

Wang M, Cheng H, Li Y, Meng L, Zhao G,
Mai K (1995) Herbs of the genus Phyllanthus in the treatment of chronic hepatitis B: observations with three preparations from different geographic sites. J Lab Clin Med 126:350-352.

Wei W, Li X, Wang K, Zheng Z, Zhou M (2012) Lignans with anti-hepatitis B virus activities from Phyllanthus niruri L. Phytother Res 26:964-968. doi: 10.1002/ptr.3663

Xia Y, Luo H, Liu JP, Gluud C (2013) Phyllanthus spesies versus antiviral duga for chronic hepatitis B virus Inspection. Cochrane Database Syst Rev 4:CD009004. doi: 10.1002/14651858.CD009004.pub2

Yano Y, Utsumi T, Lusida MI, Hayashi $\mathrm{Y}$ (2015) Hepatitis B virus infection in Indonesia. World J Gastroenterol 21:10714-10720. doi: 10.3748/wjg.v21.i38.10714

Zlotnick A, Venkatakrishnan B, Tan Z, Lewellyn E, Turner W, Francis $S$ (2015) Core protein: A pleiotropic keystone in the HBV lifecycle. Antiviral Res 121:82-93. doi: 10.1016/j.antiviral.2015.06.020 